\title{
Anticipating White Futures: The Ends-Based Orientation of White Thinking*
}

\author{
Jennifer C. Mueller \\ Skidmore College \\ DyAnna Katherine Washington \\ Independent Scholar
}

June 2, 2021

\begin{abstract}
Recent scholarship demonstrates that whites' racist action requires creativity as much as habit. Racial cognition is implicated in this behavior, as white people use ignorance and apathy to overcome epistemic challenges that threaten white power, privilege, and wealth. Using Mueller's (2020) Theory of Racial Ignorance (TRI), we show how these cognitive processes abide by an ends-based orientation - one whereby white people coordinate 'anticipated futures' to maintain the literal and psychic spoils of racism. Analyzing papers produced by white undergraduates following a project investigating systemic racism and family wealth transmission, we reveal how students' practical takeaways betray this ends-based orientation, which remains resilient amidst critical learning.
\end{abstract}

Keywords: racial cognition, racial ideology, white ignorance, antiracist practice, diversity and inclusion

* Direct correspondence to: Jennifer Mueller, Department of Sociology, Skidmore College, 815 North Broadway, Saratoga Springs, NY 12866. E-mail: jmueller@skidmore.edu. The authors extend special thanks to Kristen Lavelle, Glenn Bracey, Chris Chambers, and Joe Feagin for invaluable feedback throughout the writing process, as well as Laura Gonzalez and Laurel Gaddis for research support. Prior versions of the paper were presented at the 2015 annual meeting of the American Sociological Association and 2017 annual meeting of the Eastern Sociological Society. 


\section{INTRODUCTION}

Among everyday philosophies, "when you know better, you do better" remains a favorite. Usually attributed to Dr. Maya Angelou, a quick Google Trends Search reveals such consistent interest in this lay theory that one might assume cases of "knowing better" and not "doing better" are quite rare. Even considering a most inexorable problem of modern life - "the race problem" - people maintain a lot of hope in "the old formula": "[E]ducation leads to enlightenment. Enlightenment opens the way to empathy. [And, e]mpathy foreshadows reform," after which white people should "find it easy, or easier to give up racism" (Bell 1992:150). Unfortunately, scholarly evidence challenges such uncomplicated faith.

Individuals and groups are often invested in 'knowing badly' or evading knowledge altogether, even when knowledge and understanding are freely available (McGoey 2012; Somin 2015). Mueller's (2020) Theory of Racial Ignorance (TRI) demonstrates how deeply this phenomenon permeates systems ordered by white supremacy, where white people form attachments to misunderstanding, not knowing, and (even if they know) not caring about many things related to race and racism (Brown et al. 2019; Feagin 2020; Forman and Lewis 2015; Mills 1997). Ignorance and apathy ease the work of maintaining white domination, allowing white people to execute and abide by racism without having to look and feel "racist" (i.e. deviant and immoral). As such, these are far more than vexing, but amenable challenges; white people rely on ignorance and apathy to neutralize practical obstacles to racism, which delivers valued material ends (Mueller 2020; see also Ebert, Liao and Estrada 2020; Meghji 2019).

Even as ends animate how (and why) white thought, perception, and emotion are brought into the work of racial reproduction (Mueller 2020), many materialist theories seem to suggest that racist action results, not from white people's possessive investment in ends, but rather from their reliance on structured mental representations. This pattern holds even among the highly favored color-blind theory (CBT). CBT implies a deductive, rules-based process ties white cognition to racist action: racial ideology "furnish[es] the basic principles" white people use to perceive, 'feel,' and interpret reality (Bonilla-Silva 2001:63; Bonilla-Silva 2012; Bonilla-Silva 2018); racist action - the kind by which white people reproduce domination in the everydayostensibly follows from the problematic perception, affect, and reasoning that result. Thus, even as CBT recognizes ideologies emerge from a material order, ideology often seems to be the executive director of that order (Burke 2016; Doane 2017) - a highly structured set of mental 
rules that frustrates white people's ability to know better, producing misunderstandings that nurture apathy and racism and curb antiracism and interracial empathy (Forman and Lewis 2015). These assumptions feed a further rosy, but antithetical conclusion; namely, that education and consciousness-raising are sufficient to bring white people to the work of racial liberation.

We illustrate how TRI recalibrates that causal narrative by grounding white cognition in material ends. We demonstrate TRI's approach by analyzing the practical logics of white people who appear to renounce colorblindness in favor of "better (racial) knowing." Specifically, we examine practical takeaways communicated by white undergraduates following a research project where they successfully learned about, investigated, and analyzed systemic racism and racialized wealth transmission in their families. We identify three implied praxes - likely courses of future behavior - that accompanied students' shift to racial awareness. We find that, despite exhibiting critical racial learning in solid analyses of institutional and everyday racial reproduction and often expressing moral concern, few students express any real desire or even imagine a need to interrupt such patterns. Most stress the benefits of "knowing differently" (sometimes very ironically) and abrogate responsibility (sometimes very creatively). Further, some describe plans to maintain racist practices and recover mindsets that help them secure and comfortably enjoy what they now acknowledge are the spoils of racism. Our analysis demonstrates the ends-based cognitive orientation (Mueller 2020:149) that emboldens these practical shortfalls of critical racial learning - an orientation through which white people perpetually coordinate "anticipated futures" (Tavory and Eliasoph 2013:911) defined by sustained white domination. Through TRI, we invite forth renewed materialist analysis and more racially realistic ideas about delivering white people from a possessive investment in racial domination (Bell 1992).

\section{WHAT MEDIATES ACTION: RULES OR ENDS?}

Despite their importance, the cognitive and agentic cultural mechanisms that reinforce racial reproduction are undertheorized and reductivist in many materialist theories and accounts (Brekhus et al. 2010; Seamster and Ray 2018; Thomas 2014). The socially engendered psychology of racial domination is similarly underexplored - most especially "deep whiteness" and the internalized superiority that structures whites' racial (sub)consciousness, embodiment and practice (Bonilla-Silva 2015:83). These patterns hold even among the understandably popular 
CBT corpus (Hughey, Embrick and Doane 2015; Jung 2015). CBT emerged from Bonilla-Silva's "racialized social system" (1997) approach, which defines the racist relations from which racial subjectivities emerge and are sustained. The theory explains that material relations of domination - which organize people economically, politically, and socially into 'races' - generate not only ideological perspectives, cognitions, and emotions, but also practice. The theory is less clear in defining how racial ideologies and their distillates (like racialized emotions) work with “material force" (Bonilla-Silva 2015:78; Burke 2016; Hughey et al. 2015). Nonetheless, a deductive process, where structured mental 'rules' drive action, is implicit.

CBT argues that racial ideologies "furnish the basic principles" that people use to "to make sense of the world, to decide what is right and wrong, true or false, important or unimportant” (Bonilla-Silva 2001:62, 63). Ideologies also generate more tacit, grammar-like "rules" that "affect, if not direct altogether, our cognitions and emotions" (Bonilla-Silva 2012:176). Ideologies do more than reflect the material order in people's thinking, however; these "principles" and "rules" become "the organizational map that guides actions" in the world (Bonilla-Silva 1997:470). Though not "an explicit road map of how to act, what to believe, what to say" (Bonilla-Silva 2001:63), racial ideologies appear to work like an executive directive director of sorts: "furnish[ing] the material that is spoken, argued, and transacted," conditioning "what can be seen, understood, and even felt about matters" (Bonilla-Silva 2012:174), and thereby, animating practice.

On its face, CBT's rules-based account is appealing for its parsimonious, intuitive feel: to understand what motivates the actions by which white people reproduce racism (and resist antiracism), simply follow actors' ideological expression. Consider, for example, how scholars apply CBT to resolve a seeming paradox: racism among progressive whites. For example, studying cultural appropriation in a "conscious" hip hop scene, Rodriquez explains that "colorblind ideology ... suppl[ies] well-intentioned white individuals" with "interpretive frames and discursive opportunities to appropriate African American cultural forms" (2006:649). Because they "adhere" to its "demands," color-blind ideology leads these members to "culturally appropriate hip hop, however unintentionally, for their own purposes” (2006:649). Similarly, Burke (2011) argues the "strength of color-blind ideologies" leads progressives to recreate "white habitus" despite their sincere interest in fostering diverse communities. She reasons that colorblind dominance impedes "a coherent and utilitarian approach to analyzing and acting" in more 
materially antiracist ways; as a result, white community members "are left to act on the only means available to them - individualized, consumption-driven actions and those that keep the community safe and intact" for the interests of white homeowners (p. 660).

In these accounts, the causal effect of ideology on action appears to be a matter of deductive logic from ideas. Unfortunately, accounting for white racism in this way generates problems, which include fostering conclusions that are antithetical to CBT. CBT is clear that while racial ideology is "co-constitutive of" and necessary to "all racial domination situations," it "is not - and can never be" the cause of racial oppression (Bonilla-Silva 2015:79; Doane 2017). Still, the above analyses present racial ideology as, indeed, leading well-meaning whites astray from progressive values and into racist practice. The logically related inference is that they might do differently if only they could know differently, a conclusion that invites faith in consciousnessraising solutions. The literature reflects this pattern, too. Comparing color-blind and colorconscious childhood socialization, Hagerman concludes that color-conscious white children possess rhetorical tools for challenging and reworking dominant ideology, signaling their "hopeful" role in social change and "possibilities for future racial justice" (2014:2612). Relatedly, Trepagnier advocates helping white people understand "the racism that has occurred throughout U.S. history" - including white privilege, institutional racism, and internalized racism - arguing this kind of "race awareness in well-meaning white people is instrumental in lessening institutional racism" (2010:85). Yet, CBT is clear: education cannot "cure" racism (Bonilla-Silva 2015:76), in large part because ordinary white people are not just "cultural dupes;" they are possessively invested in systemic racial domination (and related feelings of "emotional well-being" (Bonilla-Silva 2019:7)) and use "real agency" to preserve and, when necessary, defend these material and psychic conditions (Bonilla-Silva 1997, 2001:64; Mueller 2017).

While CBT surely does not aim to produce analyses that violate core tenets, these are made easier by the theory's tacit rules-based model of racial cognition, and the ease with which users' bypass CBT's materialist mooring in "racialized social systems" (Burke 2016; Doane 2017). Bringing materialist assumptions together with the literature on culture and cognition, Mueller's (2020) Theory of Racial Ignorance (TRI) recalibrates the causal narrative. TRI explains racial cognition as motivated (Vaisey 2009; Strand and Lizardo 2015), not by rules but by ends - ends anchored by the weight of history and material relations (though not exclusively so). This approach holds focus on the fact that white supremacy nurtures possessive investment in the twin 
convictions upon which racialized modernity was built: being white is "wonderful," and "whiteness is the ownership of the earth forever and ever, Amen!" (Du Bois [1920] 2003:56; Itzigsohn and Brown 2020; Myers 2019). TRI assumes these "twin pursuits" simultaneously animate thinking, perception, affect, and practice among most whites (Mueller 2020:150).

Bringing materialist theory further into alignment with what is known about the "interior" processes that underlie action, TRI establishes that these convictions often find greatest expression in practice itself. White people ultimately reproduce (and occasionally resist) racism through practice. In that regard, white people are not simply a relational social collectivity, but a "practical group" made, remade, and sometimes reconstituted over time (Meghji 2021:351; original emphasis). Still, the vast majority of actions, including many of those that reproduce whites' dominance, reflect tacit, unarticulated beliefs (Bourdieu 1990; Jung 2015; Strand and Lizardo 2015; Thomas 2014; Vaisey 2009). Practical knowledge - the kind of belief "used to pursue a particular course of action" (Meghji 2018:235) - is less often "a 'state of mind"” or a kind of "adherence to a set of instituted dogmas and doctrines ('beliefs')," than "a state of the body" (Bourdieu 1990:68). Put differently, actors embody beliefs and motives as "capacities for action" - that is, as anticipations about one's capacity to engage in an action and the "conditions under which action is likely to unfold in the future" (Strand and Lizardo 2015:48). As such, TRI assumes that racial cognition takes place in bodies that exist as "ready for action," in continuously unfolding futures where "doing things" depends, not on mental representations, dispositions or habits, ${ }^{2}$ "but on the ways in which the world is available as a space for action" (Ahmed 2007:153; Tavory and Eliasoph 2013).

Of course, under white supremacy, different bodies experience different agentic possibilities (Seamster and Ray 2018). Whiteness works as an orientation that puts many things"tangible things, but also styles, capacities, aspirations, habits"_-"in reach." As people 'become white' they thus inherit a related sensibility about, not just the desirability, but also the "reachability" of some ends (Ahmed 2007:154, 156; emphasis added). Practical achievementsand anticipations of such achievements - thus serve as an important form of expression. Indeed, practices can reveal "minds ... at work" (Maynard 2006:105), coordinating anticipated white futures "without much comment" or even explicit awareness (Jung 2015:50-51). Nonetheless, this ends-based orientation of white thinking can be called to conscious awareness, especially during interaction. 
Interaction generates moments that interrupt the smooth (re)production of anticipated futures; one's taken-for-granted sense of reality is disrupted and they may become aware of alternative, competing, even conflicting possibilities. During such moments, actors must (re)calibrate "for concerted action to be possible" (Tavory and Eliasoph 2013:911; see also Bourdieu 1990). Capitalizing on these assumptions methodologically, we aimed to provoke white people's ends-based future-coordination "to discourse" (Jung 2015:120), using an undergraduate research project where students learned about, and then investigated and analyzed systemic racism and racialized wealth transmission in their families. Examining white students' takeaways, we explore the following questions: Do white students appear compelled to action following the "disruption" of critical racial learning? If so, what is the substance of their practical knowledge? Finally, do students' practical ideas show evidence of future-coordination; and, if so, how?

\section{METHODS}

This study examines 105 papers produced by white undergraduates enrolled in four Social Problems and Racial and Ethnic Relations courses taught by the first author at a large, public university in the southern US. We extend Mueller's (2017) prior analysis, which examined how students used creative epistemic maneuvers to avoid knowing about systemic racism. Here, we apply TRI's focus on ends to study practical knowledge (Meghji 2018).

Following a unit addressing the social reproduction of racial inequality, students collected data on intergenerational wealth transmission in their families and produced a racial analysis relating findings to course material. In preparation, content centered on: (1) the racial wealth gap and intergenerational transmission of wealth; (2) racially-exclusive historical asset policies; (3) intersections between economic and other forms of capital; and, (4) related interventions (e.g., reparations, progressive asset policies, restorative justice, individual antiracism, collective organizing) (Bourdieu 1986; Conley 2009; Darling-Hammond 2004; DeWolf 2008; Katznelson 2005; Shapiro 2005; Shanks 2005). Following several weeks of lectures, readings, and discussions, students interviewed family members and, when available, consulted personal and public histories. They explored: connections to slavery; property, money, and business inheritances; home down payment and college assistance; use of state or other asset-based programs (e.g., Homestead Act, GI Bill); social network assistance (e.g., for jobs, loans, starting businesses); and,

relatives' beliefs about family success. Students then used course material to analyze whether and 
how racial dynamics shaped family acquisition and transfer of wealth and capital. They were encouraged to explore related topics (e.g., interconvertibility of capital, white flight, segregation experiences, ideological rationales, etc.). Finally, they were instructed to share what they were taking away from the project, a direction emphasized in class. ${ }^{3}$

Data collection followed specifications approved by the Institutional Review Board (IRB) to ensure freedom from coercion. Students completed projects prior to being invited to share them for analysis; neither paper nor course grades were contingent on participation in any way; all identifying information was altered and names replaced with pseudonyms. Drawn from a larger, racially diverse sample, we analyze papers from students who self-selected "White/Caucasian" on a demographic form administered alongside consent procedures. Demographics for this purposive sample were typical for a college-aged population: most papers came from students between the age of 19 and 21 (range 18 to 37) and, typical of sociology enrollment patterns, most self-identified as female (75\%).

Though designed to support learning, students' papers speak to our questions about critical learning and practical action. Students learned "new rules" for sense-making built on race critical propositional knowledge - that is, knowledge that can be "evaluated by conceptual reason" and which "appeals to individuals as rational beings" because of its grounding in "verifiable claims about the world" (Perry and Shotwell 2009:34). They encountered scholarly evidence and theory detailing various mechanisms that reproduce the material and psychic conditions of white domination, including many that are tacit and taken-for-granted. Moreover, they examined these personally - an approach that nurtures an intimate, relational understanding about how whiteness translates to real power and greater access to resources (Perry and Shotwell 2009). These favorable conditions for learning were further enhanced by the epistemic authority of the classroom, where grades incentivize learning and students were granted space for personal and emotional processing and faced few immediate costs for entertaining course premises.

We coded papers following dictates of the extended case method (ECM) (Burawoy 1998). In contrast to grounded theory's inductive, interpretive process, ECM uses theory to target aspects of interest in the data, particularly those that allow "critical tests' of existing theory" (Emerson 2001:283). Utilizing CBT and TRI, we first coded papers holistically for overarching tone and concluding ideological orientation. This stage yielded two broad categories - papers 
exhibiting sustained colorblindness ( $\sim 25 \%$ of the total sample) or critical racial awareness $(\sim 75 \%$ of the total sample). We then turned to the latter, coding students' takeaways in terms of the logical, moral, affective, and practical insights expressed. We attended closely to the expectations that often play out in discourse (Tavory 2018) and all evidence of implied future praxes (a proxy for anticipated actions) — both explicit plans or potential actions and the 'present absence' (Mueller 2020) of practical ideas. This process of iterative coding eventually yielded saturation around patterns. We coded independently once more, to ascertain frequency, test interrater reliability, and identify exemplars.

\section{IMPLIED PRAXES OF WHITE RACIAL AWARENESS}

Prior analysis of these data revealed extensive racial privilege in family intergenerational wealth acquisition and transmission (see Mueller 2013a). Typically tracing three or more generations, white students documented numerous transfers of money, land, homes, and businesses across generations. Many of the original assets acquired and passed within students' families derived from state-supported benefits to which whites had nearly exclusive access for centuries (e.g., Homestead Act or other formal land grants; GI Bill or other state-based educational or home-lending benefits). Despite detailing plentiful evidence of systemic racism, some students maintained willful color-blind views or evaded racial analyses altogether (See Mueller 2017 for detailed analysis of ideological maneuvering). Nonetheless, nearly all exhibited some racial awareness, even those who retreated to color-blindness; and many displayed a high degree of critical racial learning. As indicated, over three-quarters of students' papers were racially aware in overall orientation.

Signaling the provocative nature of the work, many students indicated that they had not considered their personal connections to, let alone investment in racism prior to the project. Some described an initial distrust of the material, feeling "very wary of" authors' arguments and doubtful their family history would corroborate claims. Even those who were amenable shared initial trust that their "family was different," expecting to find they had "contributed very little to ... racism in the United States." Takeaways often contrasted these preliminary convictions with surprise about how much their research validated course material. Below we describe the explicit and implied practical takeaways that followed these critical racial awakenings. Three themes emerged surrounding the practical orientations of white racial awareness: (1) interventionist; (2) 
'steady state'; and, (3) racist. Table 1 outlines key dimensions of each.

Table 1: Implied Praxes of White Racial Awareness

\begin{tabular}{|l|l|l|}
\hline PRAXIS & DEFINING ORIENTATION & GOMMON FORMS \\
\hline Interventionist & $\begin{array}{l}\text { Expressed need to interrupt } \\
\text { patterns of white domination }\end{array}$ & $\begin{array}{l}\text { Assertive Intentions } \\
\text { Equivocal Intentions } \\
\text { Diffused Responsibility }\end{array}$ \\
\hline Steady State & $\begin{array}{l}\text { Racial knowing as an end } \\
\text { No further praxis implied }\end{array}$ & $\begin{array}{l}\text { Racial awareness as 'real' } \\
\text { Racial awareness as unpleasant } \\
\text { Racial awareness as reward } \\
\text { Racial awareness as praxis }\end{array}$ \\
\hline Racist & $\begin{array}{l}\text { Expressed expectations to } \\
\text { reproduce mechanisms of white } \\
\text { domination }\end{array}$ & $\begin{array}{l}\text { Explicit Intentions } \\
\text { Projected Colorblindness }\end{array}$ \\
\hline
\end{tabular}

\section{Interventionist Praxis}

Interventionist praxis surfaced when white students indicated any need or plan to counter racism with actions of any kind. About a third of the subsample offered such takeaways. As suggested above, students were often taken aback by findings. Liz was uniquely disturbed. She acknowledged that she "never had to face these issues" before, because she lived in a society that shields white people from understanding their involvement in systemic racism, continuing:

Knowing that my family lineage, and the life that I live today, all contribute to systemic racism is infuriating. Now that I am aware of the injustice that is present, I feel an obligation to work against it. I do not know what exactly this looks like in my own life yet. It could mean living in a predominantly black neighborhood to promote integration, working in a racially diverse job, or simply telling people about what I have learned to educate others [who] may be oblivious to the racialized society in which they live, a practice I have already started. 
By her own testimony, Liz had not thought much about racism prior to the project, let alone her own complicity. Her critical learning ignited both a sense of moral outrage and related (if still evolving) plans for practical antiracism - a shift in behavior Liz reported she was already enacting.

Despite how often white students shared being surprised and unsettled by their findings, unlike Liz, few claimed a sense of personal responsibility to interrupt racism now or in the future. Among students exhibiting critical racial learning, only a handful offered such testimony. Sasha stated that she believed she "must take some responsibility in correcting inequality." She clarified, though, that she had decided to pursue a social work career even prior to the assignment because she was "an idealist" and "very passionate about doing [her] part to help those who are oppressed.” By contrast, Emily reported her research and subsequent reflection had kindled "a passion of wanting to help people that are less fortunate than me." However, this impulse was followed by a strange, paradoxical goal - "travel[ing] to other countries."

Students' analyses of policies and everyday practices that reproduce the racial wealth gap were typically thorough and detailed. Yet, as reflected in Sasha and Emily's responses, ideas for personal interventions often bore little resemblance to the inequalities examined - a notable disconnect. Some expressed undefined, but still related commitments, like Heidi, who declared her "eyes ha[d] been opened" to the circumstances that "perpetuate inequality and how I may go about fairly distributing my personal wealth ... for the benefit of others when I depart into the real world." But Liz was the only student to venture a connected (though arguably misguided) personal intervention: learning that racialized housing markets devalue communities of color and hyper-develop white wealth, she considers the possible benefit of integrating a Black neighborhood. Equally striking, despite the fact that racist asset-policies were a primary focus of students' research and policy remediation was covered in course lectures and readings, only two students invoked related public interventions. Both referenced course readings that proposed policy options, like Natasha, who argued it was "clear" that such policies "need[ed] to be enacted" to "help remedy" issues related to asset-poverty. Although highly infrequent, antiracist takeaways that targeted inequalities examined by students were clearly not inconceivable.

More commonly, interventionist takeaways focused on "knowing better." For a scant few, this goal was personal. Amanda realized how internalizing a white racial frame (Feagin 2020) distorted her understanding, continuing, "[t]his is something I need to work to remove and every 
day I continue to work on that." Paul felt a "streak of motivation" to develop an "elaborate" understanding of his family's background so he could "spread" his "new mentality" to help "future generations." Students often spoke about "knowing better" in this self-evident way, as an important step that presumably leads to progress. Some better clarified how this worked, like Kendall, who explained:

We, as an American people need to become aware of these truths and understand the implications of colorblindness in our society. By doing so, we can all become advocates for a truly equal society where policies assist African Americans in narrowing the wealth gap. The only thing that stands in the way of this change is an open mind.

As opposed to a personal goal, Kendall speaks on behalf of a generic (implicitly white) American "we," expressing a faith that if this collective can just open their minds they will renounce colorblindness and "become advocates for a truly equal society." Relatedly, Parker declared: Just because I am a beneficiary of the system does not mean I cannot work so that others may experience the same benefits as I have. When we equip ourselves with this knowledge, it is here where we can effectively make a difference.

Despite linking "knowing better" with "doing better," Parker asserted no particular commitment or ideas about how to "make a difference" - only that it was something he and presumably any white person who "equips themselves" with knowledge could do.

Indeed, Parker begins his testimony speaking from the "I," but like Kendall, retreats to a more generic "we." We observed this pattern many times: students testifying about prior racial ignorance, asserting racial knowing as an obvious corrective, then diffusing responsibility for practical action across a broad white collective. Over half of all interventionist takeaways followed this approach. Perhaps students recognize structural change requires collective engagement. Some were very clear that racial inequality would continue "until whites begin to take a stand and correct the wrongs that have continued ... for so long," as Jay wrote. And given the deeply institutionalized and hegemonic nature of white domination, critical understanding is surely a necessary ingredient of mindful antiracism (Perry and Shotwell 2009). Still, the trust that white people who 'wake up' will translate knowledge to action rests on tacit trust in whites' fundamental virtuousness, one that students' own narratives defy. The impersonal quality of students' practical ideas appears conspicuous against the backdrop of their personal analyses.

Some discussed responsibility in even more obscuring ways. After describing her 
relationship to racial inequality in active detail, Trisha concluded passively: "Therefore attention must be paid to the fact that non-white people not having the ability to grow this wealth are at a great disadvantage even with high incomes." Beyond obscuring why "paying attention" to Black disadvantage is important, Trisha's passive voice also hides who should be doing the work of noticing. Melanie developed an even more perplexing takeaway. She admitted that the ways her family gained wealth and power made her "upset," and acknowledged "[t]here are still problems and we still add to ... colorblindness." However, with an almost magical confidence, she pivoted to describe how her family was "making every effort to move forward and to help make this world a less discriminating place to live":

...I know [our racism] is not on purpose and that is why I know that we will make a positive impact on the march to equality. I think that with the wealth and capital that we have obtained over the years we will use it in ways that will help for the better. Learning the knowledge that I am learning in my classes will help me to teach my children the way things should be, in hopes that they will be able to use their wealth for the good of others. I feel like my family is a great example of each generation changing to make the next generation a better one.

By her own evidence and analysis, Melanie's family was, in fact, a "great example" of various mechanisms that maintain white power, privilege, and wealth. Nonetheless, she projects an alternative reality defined by antiracism. From the unconscious racism of past and current generations through the projected antiracism of future generations, Melanie enshrines the morality of her family (and her family's unjust enrichment) in perpetuity.

Some students' interventionist ideas negated their own sharp analyses. Carla discussed how "ignor[ing] the ways that race shapes our lives" works to "reinforc[e] the existing racial hierarchy." For her, "the scariest part" was learning, not just "how blind we are to race," but also "how that works for us" - a takeaway that emerged from challenges she faced securing her family's help with the project. She believed her father "brushed [her] off”' specifically because the assignment rubbed him "the wrong way." Ultimately, however, Carla's practical ideas focused squarely on learning:

We have to realize how we got to where we are and examine why we were given the resources we have. We need to ask ourselves: how would our lives be different had we not been born white? ... It is then that we can begin to get educated and solve the problem of 
systemic racial inequality.

Carla gained powerful insights that colorblindness involves an active resistance that "works" for white people, materially and psychologically (Mueller 2017). Nonetheless, she preserved hope that "getting educated" will compel white people to "solve" racism.

Students also wrestled with practical and moral imperatives. Laura's analysis, detailing how privileges she enjoyed were connected to "the unjust impoverishment of others," left her with "a daunting question: How can I help the 'larger issue of systemic racial inequality?"” Rather than broaching possibilities, Laura pivoted to questions of a different type: "Is it my responsibility to change this? Should I feel guilty about what I have? Will I be the only person of my race fighting for a never-ending cause?" Similarly, Abby testified that her "eyes [had] been opened to the process by which" privilege and wealth had "been made available" to her family while "[m]any people, equally if not more, worthy of all my family has" were held back. More importantly, she stated the project "made this issue a personal one. I have realized that everyone, even the 'good' people are involved in systemic racism. I have seen how I have added to this problem." Despite firm intellectual, moral, and personal takeaways, Abby followed, too, with not with practical commitments, but questions: "I am left not knowing what to do with that. Should I feel guilty or blessed, do I fight the system or are we too far embedded in this ideology to get ourselves out?"

Laura and Abby's grappling appears sincere and, given the depth of the problem, is perhaps understandable. Still, future actions hang in the balance of their answers to these telling questions, which beyond pragmatic challenges, adjudicate the rationality of emotional and moral investments. Read this way, their inquiries make space to build a case against antiracism. Indeed, Laura layered discouraging arguments onto her questions:

As a race we are not able to see how the color of our skin plays into our wealth, and then once we do recognize this, we do not know what to do to help the situation. From my vantage point it seems like a battle that cannot be won alone. Until white people stop rationalizing racial oppression and start realizing their own role in racial oppression, systemic racism will continue to flourish.

In practical terms, each of Laura's takeaways - from her initial questions to these statementsbuild toward a damning conclusion: individual antiracism is pointless unless masses of white people agree to recognize and halt their roles in perpetuating racism. She argued that "covert 
racism continue[d] to thrive" because "[q]uestions like these remain unanswered," both by herself and "the majority of the white race." But, practically speaking, Laura's questions seem more answered than not: individual antiracism is, at best, a mood - not a reasonable practice.

Similarly, Abby's equivocation betrays the trust she had that her family "would have made different decisions" if at any point they were "told they were putting a group of people at a disadvantage." Despite knowledge of ways she "added to this problem," Abby felt "helpless." Like the sincere, but dubious nature of Laura's "unanswered" questions, Abby is only "helpless" if the only actions worth considering are ones that destroy systemic racism like a bullet. Like others, Abby and Laura's takeaways expose how students used a corporate white calculus to deliberate, diffuse responsibility for, and, when necessary, rule out practical antiracism.

Despite the common hope that white people who "know better," tend to "care more," and thereby "do better," with few exceptions, interventionist takeaways were largely rhetorical and circularly reinforcing. Glazer and Tiebow note that whites commonly identify "partners in crime" to manage culpability _-"If everyone else is just ... as guilty ... then white people needn't be singled out and held accountable for racism" (2020:11). Here, students largely deflected responsibility for action, placing onus on an abstract white American collective. Further, some further invoked corporate white politics to cast doubt on other whites and reason their way out of practical adjustments.

\section{'Steady State' (No Implied Praxis)}

Most students who demonstrated critical racial learning exhibited a praxis we call steady state. Originating in exercise science, this concept refers to a metabolic plateau that follows rapid transformation or change, such as when a runner bursts to a sprint before settling into a comfortable pace. Analogously, steady state appeared in papers where students developed critical analyses, followed with various logical and emotional takeaways, and peaked there, offering no further practical insights. ${ }^{1}$ In other words, beyond knowing about it, white students exhibiting steady state shared no practical ideas related to racism.

Steady state takeaways seemed to imply racial awareness as a worthy end unto itself, though logics as to why varied. Many focused on corroborating what was "real" concerning racism and racial inequality. For example, Tiffany concluded:

Racial inequality is a reality and I am guilty of thinking that it does not exist anymore.

Colorblind racism is real and it describes me. A lot of the hidden costs [of being African 
American] are things that I was not aware were actually happening. ... I am taking away knowledge that I did not have before about assets that I have access to ... that other people do not.

Takeaways of this sort were common - authorizing systemic racism, racial inequality, and white privilege as "indeed very real," sometimes alongside confessions about having overlooked this "reality." Another student, Allison, testified: "Inequality affects real people.... It's just because I won the genetic lottery that I'm not on the other side of the issue. I'm not entitled to this lifestyle. It's just the way it ended up." Allison recognized how arbitrary her racialized good fortune was and how different her family's history might have been were they not white. Still, Tiffany and Allison's newfound grasp on "reality" - including knowledge of the exclusive advantages whites enjoy and costs people of color pay as a result - failed to spark further concern.

For some, embracing the "reality" of racism triggered a more troubling dissonance. Subsequent takeaways described racial awareness as an undeniable, yet unpleasant truth. Andrea shared what a "hard realization" her "plainly obvious" conclusions were, "especially since my family stresses equality between all races, religions and creeds;" still, she believed this was "the unfortunate truth." Similarly, Colin "found many of the arguments" held "true" for his family, which disturbed him:

$[\mathrm{T}]$ heories of systemic racism, unjust impoverishment, white privilege, and transmission of wealth are not easy to accept or swallow. They attack that which many people (including myself) wish was purely the result of hard work. ... While most of my family worked very hard, they also were allowed to many times due to advantages they did not realize they had, an argument ... that is still hard to accept. Systemic racism is real, and it does affect us much more than is realized.

Students like Andrea and Colin seemed disappointed to learn how indefensible colorblind logics were in light of their findings. Implicit, too, is a sense of moral failure. Nonetheless, like Tiffany and Allison, Andrea and Colin peaked at logical and emotional takeaways, offering no further ideas about the need for interventions - even despite believing that racism violated cherished personal values.

As consistently as upset, many described new racial awareness as "rewarding" - a fruit of the learning process they were "intrigued" by and thankful to reap. For instance, Julie reported how "thoroughly" she "enjoyed researching on the internet, interviewing my family, reading [the 
course text], and putting together this paper." She felt like the work had "enlightened" her "by showing the importance of race and class in the intergenerational transmission of wealth and capital within my family." With a similar, happy satisfaction, Anya recounted how "interesting" her findings were:

I put the pieces together and saw how my family has benefited from the institutions in place, all of which had some dependency on the color of my skin. ... I enjoyed finding out about how our family gained its wealth through the GI Bill [and] the way [ancestors] purchased and sold their Texas land, giving them financial security that has profited the family all the way down to me.

Julie and Anya recognize that their enrichment is rooted in systemic racism - "all the way down to me," as Anya stated. However, neither appear concerned about the impoverishment people of color experience as a result, nor deterred from enjoying their newfound understanding about the various ways their families accessed and maintained exclusive privileges.

Relatedly, students' learning often engendered deep feelings of gratitude - like Vanessa, who said she appreciated her family and their background "that much more" now. More striking, many were thankful for what must be described as the spoils of racism. Angela equated white privilege with being "spoiled," something she confided she had "always tried to convince [her] self and others" she was not. Nonetheless, her "personal family history helped paint a portrait of the issue of racial inequality":

It made me realize all the opportunities and advantages that my family, and whites in general, have access to.... I am extremely grateful for all I have; I do not see myself trying to convince anyone that I am not spoiled anytime soon.

In similar fashion, Regina granted that "a lot" of her family's wealth derived from whiteness, leaving her feeling "more grateful than ever to have had so much." Although she might "never be as rich as Bill Gates," she still believed she "surely" had reason to feel "thankful." Others felt not only "humbled," but more respecting of people of color, like Matt, who believed he would "better appreciate the struggles of lower-class minority families" and "admire" economic peers, given he now realized "that person's ancestors will have worked harder to get to where they are today." Feeling grateful for racism may seem like an absurd, even disturbing takeaway, but it implies a practical-moral commitment nonetheless: namely, to acknowledge, be more mindful of, and appreciate resources and opportunities acquired through white domination. 
The abundance of steady state takeaways may reflect a belief that knowing about racism is, itself, a helpful (and generous) practice for white people. Perhaps many - so "previously unaware," "shocked" and "intrigued" by their own findings - interpret new racial awareness as a flattering, even promising testimony. Some were explicitly optimistic, like Rose: "Hopefully, students in the future can look back at their family's wealth and resource distribution and see how far their society has come in making racial equality a normality." Yet, as the project is designed to lay bare, racial orders emerge no more magically than do racial remediation, equality, and justice, marking the significance of such a "plentiful absence" of practical takeaways.

\section{Racist Praxis}

About $10 \%$ of students exhibiting critical racial learning indicated a likelihood, in some cases certainty, that they would maintain practices that secure whites' privileged access to wealth and capital. We coded racist praxis among these students, who embraced critical logics in principle but (in terms of practice) indicated they would knowingly, if regrettably maintain privileged advantages; or, be unable to retain critical learning and thus unable to not reproduce racism.

In one salient example, Josh (a senior at the time) shared plans that were more than speculative:

My fiancé and I are buying a house in [well-established metropolitan area] when I graduate and get the job I mentioned earlier. In our search we logically prioritized good schools as our main focus. An unfortunate side effect of this goal is that it perpetuates the cycle of inequality that exists between the education of whites and non-whites ... because racial segregation leads to differences in property taxes, which leads to differences in educational quality, which leads to job differences which causes residential segregation. Here and throughout, Josh demonstrated a firm understanding of the dynamics that reinforce disparities in housing, education, and wealth, conditioning patterns of residential segregation and white flight. He detailed how privileged opportunities had shaped his life (including an upcoming job he acquired through white networks); he acknowledged, too, how racial inequality is "amplified as wealth and capital are passed down from generation to generation." Yet, as "unfortunate" as the "side effects" of his future actions might be, the definitive nature of his plans showcase an economics-centered rationality that nullifies ethical concerns. Josh closed with a wish: "hopefully this paper can bring to light and illuminate much of what is forgotten or ignored 
in present day racial discourse." In other words, perhaps he can help others' "know better" in a way that leads to less injustice. Of course, his own testimony casts doubt on this strategy.

Some communicated racist intentions in even more matter-of-fact ways. Lily shared how "interesting" it was "to see that all of the things" discussed in class "applied directly to [her] family's history." She continued:

I definitely learned that in order to be racist you don't have to [engage in explicit racism], but by continuing the life I'm living ... racism will not stop any time soon within my own family. I can understand why my grandparents did the things they did because all they wanted was the best that was possible for their children, and that is what my parents want for me and I will want for my children as well. Also, it definitely clarified why blacks still have such a hard time in our society today; they will never be offered the opportunities or have the social network I have as a white person.

Lily articulates a taken-for-granted horizon of perception: one where Black people "never" receive the same opportunities as whites, white people do "understandable" things to maintain racial advantages, and racism never ends; in short, an intergenerational reality defined by perpetual white dominion (Myers 2019). Unlike Josh, Lily doesn't seem to wish things could be different or express concern about the Black people impacted. Distinctions aside, recognizing that their advantages accrue at the expense of Black people does little to alter either students' practical compass. Both imply there is but one "logical" way forward, and neither reject racism in a meaningful way, nor entertain that caring for one's family is not mutually exclusive from caring for others.

Racist praxes rarely exhibited this sort of raw transparency. Paradoxically, some predicted future racist actions alongside an attendant colorblindness. For example, Emily speculated about a future that resembled Josh's in many respects, but her reasoning took some puzzling turns. She bemoaned the explicit racism of her family and regretted the bias she internalized from this socialization. Still, although she "would like to break the cycle of [her] family being racist," she had to "admit that when looking for a home with my husband after college, I will consider the schools that are present as well as the ethnic background because I would like my children to have the best education possible." She recognized her actions involved "discrimination" that helped to reproduce racism and felt "guilty" thinking about "all the people [who] have so much less than me.” However, she characterized her involvement strangely — as 
one "where even I the least judgmental person will unknowingly be racist" (emphasis added).

Katrina, too, used contorted reasoning to chip away at antiracist hopes. She declared "[s]ystemic racial inequality is still alive today and it won't be going away anytime soon," and described how finding out how she was "connected to" this inequality was "a disappointment. It's a disappointment because I know that unconsciously I am likely to follow in the steps of keeping racial segregation alive." Ironically, she immediately detailed how this future "unconscious" racism was going to play out, describing concrete examples of everyday racial reproduction uncovered in her research and how these were going to continue. She then pivoted back to the idea that racism was "embedded in the back of [her] mind." She "would like to think" that her generation "could be the generation to close the wealth gap and racial segregation," but her research made it clear it was not "that easy." Building from this belief in racism as a foregone conclusion, Katrina offered plans to be more grateful: "Knowing that not every race can be so lucky" made her "want to succeed and not take for granted the ... wealth and capital that my family has been able to accumulate over time."

Katrina and Emily's testimonies — predicting a future where they "accidentally" reproduce racism because they fail to know things about which they have demonstrated significant knowledge and concern - seem illogical on their face. However, their irrationality becomes legible when we interpret their reasoning as ends-based: focused on the practical goal of doing what one needs to do to maintain white privilege and wealth and the psychic goal of not "being racist" (i.e. deviant or immoral). While it requires some mental gymnastics to get there, both Emily and Katrina successfully neutralize the practical and moral implications of their racial awareness by reasoning backwards, such that any future failure to not reproduce racism seems innocent.

Some used more straightforward logics of "structural reification" to pursue similar ends, implying structures were "responsible" for racial reproduction. For example, Lexi argued that because racial inequality was "structured into society," white people are "faced with a path of least resistance in which racist decisions have to be made for upward mobility" (emphasis added). Macy engaged similar ideas in a more personal way. She claimed that to "a certain undeniable extent," she was "better situated" for various "career and financial goals when compared to an African American girl of my same age that happens to live in ... a city that I grew up not 30 minutes away from." Despite believing these social facts were "undeniable," Macy closed by 
arguing, "I do not perpetuate this injustice consciously or even by the daily decisions I make, but as Linda Darling-Hammond [(2004)] would say, 'until these inequalities are confronted and addressed, we will never get beyond the problem of the color line’ [(p. 214)].” Macy passively diffuses responsibility for "confronting" and "addressing" racism. But beyond that, she and Lexi diffuse blame for reproducing racism, too, implying it is simply impossible for white people to do anything else. The result is an insulating reality where white people are neither responsible for doing racism nor for stopping it. In that regard, they set themselves up for the same practical future as do others' more explicit plans.

\section{CONGLUSION}

In Faces at the Bottom of the Well (1992), Derrick Bell reflects on Ursula Le Guin's haunting tale, "The Ones Who Walk Away from the Omelas." The story describes an idyllic, magical community of prosperous, joyful people. Even as they experience "neither crime nor want," they face one considerable problem: their happiness depends on the "abominable misery" of a child. Condemned to a small, dirty room in the basement of a lavish public building, the child regularly pleads for release - malnourished, neglected, afraid. Some "have come to see it, others are merely content to know it is there." But whether on faith or full understanding, all in the Omelas know: to maintain their happy existence, the child must suffer (p. 154-155).

Bell argues that white domination, too, exists as an "open secret," one that bonds whites like the people of the Omelas, in a "knowing but unspoken alliance" to racism; "an amalgam of guilt, responsibility, and power - all of which are generally known but never acknowledged" (Bell 1992:155; see also Cottom 2019). Indeed, knowing about racism, however dimly, is what makes racism valuable to white people; knowing about the literal benefits that whites enjoy as a result of Black subordination that nurtures allegiance to "the racial status quo" (Bell 1992:151). This tacit understanding of material reality and responsibility fuels what we call the ends-based orientation of white cognition: a self-deceptive, social process (Mills 1997) through which white people perceive, think, and feel in ways that help maintain their morally compromised status as "wonderful" owners "of the world forever and ever" (Du Bois [1920] 2003:56).

We argue that students' takeaways expose their tacit efforts to coordinate "anticipated futures" defined by these ends (Tavory and Eliasoph 2013:911), and their pragmatic understanding that performing, abiding by, and enjoying the spoils of racism without suffering 
the moral cost is an outcome well "within their reach" (Ahmed 2007:153-154; see also Strand and Lizardo 2015). To be sure, students appeared to learn a great deal from the assignment. Their insights captured critical understanding about systemic racism, their complicity in reproducing it, and oftentimes emotional engagement with the topics at hand. However, for all their learning we observed very little appetite for, or even basic impulses to intervene on the status quo - evidence captured in the "presence" of what students spoke to and the "absence of understandings, feelings, and moral judgments that could" and, from some perspectives, should have been present (Mueller 2020:146). Any confusion about these practical shortfalls of learning clears, however, once we put down the idea that racist action is driven by faulty mental rules that generate problematic thinking, feeling and, thus, doing among white people.

From TRI's perspective, students' reasoning evinces, not problems, but pragmatic solutions to problems. Executing and abiding by racism generates perpetual challenges that must be overcome. These include an empirical reality filled with damning evidence (Mills 1997; Jung 2015); the cognitive dissonance of violating not just explicit values, but a "deep-lying human propensity to interpersonal empathy" (Feagin 2020:251); and the inevitable resistance of those harmed (Bonilla-Silva 2001). White people have developed many "habit sets" (Gross 2009:371) to manage these threats to racial reproduction - consistent repertoires of cognitive and affective dysfunctions that help twist reality (Mills 1997; see also Bracey and McIntosh 2020; Glazer and Liebow 2020; Lavelle 2017; Salter, Adams, and Perez 2018) and deaden normal human empathy (Feagin 2020). Habits ease the work of racial reproduction considerably by helping white people manage what they know and how they feel (Ebert, Liao and Estrada 2020; Yamashita 2020); but should pre-existing habits fail, creativity kicks in to solve practical challenges that "rise to the forefront of consciousness" (Gross 2009:366; Mueller 2017).

We illustrate how students metabolized critical racial learning with both habit and creativity to coordinate futures built around intergenerational white domination. To be sure, learning raised serious cognitive dissonance and empathic concern for some - "moments of disjuncture" requiring that students "calibrate" for future racist action "to be possible" (Tavory and Eliasoph 2013:911). These students creatively solved problems of knowing and caring using an "antisocial math" (Jung 2019:165) that allowed them to sacrifice concern for others (Bell 2004). They betrayed their own knowledge, reasoned their way out of compassion and accountability, and hedged bets in a "veneer of consensus" (Tavory 2018:125) with a generic 
white collective who "don't know" and "don't care." Further, some used magical thinking to legitimize ongoing racist practice and project regressive future mindsets where they can maintain racism without knowing or feeling badly about it. However, others' habit sets were so secure that critical racial learning necessitated slight, if any adjustments. They conceded a technical role in reproducing racism, but that did little to trigger accountability. Many peaked at knowing about racism and expressed concern only in self-referential ways. And some appeared so captured by the idea of intergenerational white domination that they experience it as not just immutable, but natural, even sacrosanct. Among these students, there is no moral innocence to repair, because they do not even recognize it as threatened (Jung 2015).

These theoretical takeaways invite important empirical insights; specifically, concerning the benefits of using strategic disruption as methodology. Such an approach helps resist culturally reductive accounts that mask white agency, motive, and creativity. Indeed, because CBT directs attention to a structure of rules that propel white cognition, affect, and practice, applications tend to emphasize, not "conflict as the crucial driving force" of racialized social systems (cf. BonillaSilva 2015:77), but stability. Our approach makes clear, however, that the stability of white domination must be achieved in the face of continual challenges, some of which are explicit. TRI thus aligns with the wisdom of cultural and interactionist scholars: any stable rhythm of white thought, emotion, and behavior "needs to be understood in relation to the moments in which the regularities of social life are ruptured" (Tavory 2018:128). Thus, we urge further disruptive approaches that "awaken" white people's creative resistance and related motives "into discourse" (Jung 2015:120). Doing so here, we revealed that white people's racist practical knowledge and 'groupness' is incredibly resilient, even in the face of challenge, and significant learning and concern. Further, we exposed specific cognitive tactics white people use to coordinate future racism by restoring their symbolic innocence and the veneer of consensus. In other words, using TRI we exposed that the "fractures of whiteness" do not "heal fast" on their own (Bonilla-Silva 2019:14); white people often must heal them through creative efforts.

While our focus is micro-analysis, researchers can also use a TRI-based approach to surface how white people use organizations and institutions to coordinate white futures. To be sure, elites regularly "program" the habit sets of whiteness into "organizational logics and practices to facilitate desired ends" (Mueller 2020:151; see also Moore 2020). Doing so creates affordances for white ignorance and apathy by masking white interests as "common interests" 
and making privileged ends easier to pursue. To that extent, ethnographic and organizational researchers can also capitalize on disruptive methodologies, interrupting the smooth reproduction of racism in local contexts, especially with institutional decision-makers, and thereby rendering tacit agency visible (Jung 2015; Mueller 2020). Indeed, connecting analyses to concrete material contexts is vital (Burke 2016), and TRI invites consideration of how anticipated ends arise from multiple, intersecting factors that include social positionality, political orientations, subgroup affiliations, individual biography and even psychology, not to mention the localized particularities of transnational racial fields (Christian 2018). Moreover, TRI's focus on ends invites more serious attention to people like Liz, exploring the conditions that lead some whites to coordinate anomalous futures, committing to antiracism in word and practice. (See Mueller 2020 for further TRI-based research ideas.)

Finally, our analysis exposes essential practical implications. Truly, it is telling that white students' hegemonic explanations - advocating better knowing as a solution and naturalizing structures in ways that characterize white people as passive, and thus innocent agentssometimes map onto our own hopeful conclusions. Granted, one semester's learning does not a "new racial project" make (Burke 2011:662). Still, consider how rarely students rejected racism unequivocally; it almost never rose "to the forefront of consciousness" (Gross 2009:366) as a problem in need of real solutions. In this absence sits evidence of whites' attachment to racism and resistance to remediation. To paraphrase Bell, "we fool ourselves when we argue" that racial ignorance is the problem that must be overcome; indeed, believing so is itself a type of racialized ignorance about white ignorance (1992:151). Quite the contrary, the project may have actually increased some students' investment in racism by making its literal value undeniably clear. Now, consider how many organizations entrust singular educational programs - diversity courses, antiracism workshops, and the like - not only to improve racism in institutional cultures, but also to shape a broader citizenry dedicated to equity and justice.

Our findings expose that these types of quick fixes cannot begin to address the depth of the challenge. Worse, in granting the symbolic cover of "progressive action," they all too often worsen racist injuries. To the point, recent research documents that many higher education approaches to diversity and inclusion not only fail to address racial injustice and related moral concerns, but they also reinforce and quite literally reward white people's instrumental preferences at the literal and psychological expense of Black students; moreover, students, 
families, and institutional officials indicate they expect these racially discrepant outcomes (Stark, Sinclair, and Shelton 2021). Findings from corporate and other institutional settings cast further suspicion on the $\$ 8$ billion dollar a year "diversity industry" (and its many white professionals) (Pan 2020).

Rather than become disheartened by such findings, we should take inspiration, and consider the leverage gained by resisting rosy explanations and refusing to promise anything about how whites' possessive investments can be undone, and better angels brought forth through educational interventions. Far from essentializing white people, this stance keeps open "the force of the critique" (Ahmed 2007:165), disrupting the unreality of "race" and supporting everyone sincerely concerned with developing the kind of "cosmic discontent" and "creative maladjustment" (Allen and Leach 2018:317) that feeds real, material antiracism. After all, one cannot "confess" or think their way into the undoing of privilege (Yan et al. 2021); creating structures that dismantle the systems that enable privilege is the only thing that can deliver on that end. All educational and ideological interventions should begin from this premise, and make way, too, for further, more liberating epistemologies - the kind that help people dream up freer, futuristic realities "somewhere in advance of nowhere" (Cortez 1996).

\section{NOTES}

${ }^{1}$ We credit Laura Gonzalez for devising this novel application of steady state.

${ }^{2}$ Borrowing from Bourdieu, Bonilla-Silva introduced the concept of "white habitus" to address the routinized, pre-reflexive, practical dimensions of white cognition. Bonilla-Silva describes white habitus as the "racialized, uninterrupted socialization process that conditions and creates whites' racial taste, perceptions, feelings, and emotions and their racial views on racial matters" (2018:121, emphasis in original). Because Bonilla-Silva is most attracted to the idea that habitus facilitates racial reproduction of domination "without express calculation" (2018:279), his theorization appears too deterministic to truly engage the dialectical, agentic aspects of habitus (Hagerman 2016), or his own principled commitment to the idea that occasional fractures and vulnerabilities can disrupt this smooth reproduction of whites' racial standing (Bonilla-Silva 2019). As we capture in our analysis, this threat of disruption is, in fact, continual; as such, TRI defines how cognition is oriented in a way that helps white people consistently defend against epistemic challenges using both habit and creativity. Notably, this claim is in keeping with Bourdieu's (1977:169) observation that dominant groups' will effort to restore their cognitive "innocence" about the game being rigged in their favor when such a fact is exposed.

3 The assignment is described in full detail in Mueller 2013b, and is available by contacting the first author. 


\section{REFERENGES}

Ahmed, Sara. 2007. "A Phenomenology of Whiteness.” Feminist Theory 8(2):148-168.

Allen, Aerielle M. and Colin Wayne Leach. 2018. "The Psychology of Martin Luther King Jr.'s

'Creative Maladjustment' at Societal Injustice and Oppression.” Journal of Social Issues 74(2):317-336.

Bell, Derrick. 2004. Silent Covenants. New York: Oxford University Press.

-----. 1992. Faces at the Bottom of the Well. New York: BasicBooks.

Bonilla-Silva, Eduardo. 2019a. "Feeling Race: Theorizing the Racial Economy of Emotions."

American Sociological Review 84(1):1-25.

-----. 2018. Racism without Racists. $5^{\text {th }}$ ed. Lanham, MD: Rowman \& Littlefield.

------. 2015. "More Than Prejudice: Restatement, Reflections, and New Directions in

Critical Race Theory." Sociology of Race and Ethnicity 1(1):75-89.

-----. 2012. "The Invisible Weight of Whiteness: The Racial Grammar of Everyday Life in

Contemporary America." Ethnic and Racial Studies 35(2):173-194.

------. 2001. White Supremacy and Racism in the Post-Civil Rights Era. Boulder, CO: Lynne

Rienner.

------. 1997. "Rethinking Racism: Toward a Structural Interpretation." American Sociological

Review 62(3):465-80.

Bourdieu, Pierre. 1977. Outline of a Theory of Practice. New York: Cambridge University Press.

------. 1986. "The Forms of Capital." Pp. 241-258 in Handbook of Theory and Research for the

Sociology of Education, edited by J.G. Richardson. Westport, CT: Greenwood Press.

-----. 1990. The Logic of Practice. Stanford, CA: Stanford University Press.

Bracey, Glenn E. and David F. McIntosh. 2020. "The Chronicle of the Resurrection Regalia: Or

Why Every Black Hire is the First.” American Behavioral Scientist 64(14):1961-1974.

Brekhus, Wayne H., David L. Brunsma, Todd Platts, and Priya Dua. 2010. "On the

Contributions of Cognitive Sociology to the Sociological Study of Race." Sociology Compass 4(1):61-76.

Brown, Tony N., Asia Bento, Quintin Gorman, Lydia Koku, and Julian Culver. 2019. "'Who

Cares?': Investigating Consistency in Expression of Racial Apathy by Whites." Socius 5:110.

Burawoy, Michael. 1998. "The Extended Case Method." Sociological Theory 16(1):4-33.

Burke, Meghan A. 2011. "Discursive Fault Lines: Reproducing White Habitus in a Racially

Diverse Community. Critical Sociology 38(5):645-668.

-----. 2016. "New Frontiers in the Study of Color-Blind Racism: A Materialist Approach."

Social Currents 3(2):103-109.

Christian, Michelle. 2018. "A Global Critical Race and Racism Framework: Racial

Entanglements and Deep and Malleable Whiteness." Sociology of Race and Ethnicity 5(2):169185.

Conley, Dalton. 2009. Being Black, Living in the Red. 10 ${ }^{\text {th }}$ Anniversary ed. Berkeley, CA:

University of California Press. 
Cortez, Jayne. 1996. Somewhere in Advance of Nowhere. New York: High Risk Books.

Cottom, Tressie McMillan. 2019. Thick: and Other Essays. New York: The New Press.

Darling-Hamond, Linda. 2004. "The Color Line in American Education." Du Bois Review $1(2): 213-246$.

DeWolf, Thomas. 2008. Inheriting the Trade. Boston: Beacon Press.

Doane, Ashley W. 2017. "Beyond Color-blindness: (Re)Theorizing Racial Ideology." Sociological Perspectives 60(5):975-991.

Du Bois, W. E. B. [1920] 2003. Darkwater. Amherst, NY: Humanity Books.

Ebert, Kim, Wenjie Liao, and Emily P. Estrada. 2020. "Apathy and Color-Blindness in Privatized Immigration Control." Sociology of Race and Ethnicity 6(4):533-547.

Emerson, Robert M. 2001. Contemporary Field Research. Prospect Heights, IL: Waveland Press.

Feagin, Joe R. 2020. The White Racial Frame. New York: Routledge.

Forman, Tyrone A. and Amanda E. Lewis. 2015. "Beyond Prejudice? Young Whites Racial Attitudes in Post-Civil Rights America, 1976-2000." American Behavioral Scientist 59(11):1394-1428.

Glazer, Trip and Nabina Liebow. 2020. "Confronting White Ignorance: White Psychology and Rational Self-Regulation.” Journal of Social Philosophy. DOI: 10.1111/josp.12349

Gross, Neil. "A Pragmatist Theory of Social Mechanisms." American Sociological Review 74(3):358-379.

Jung, Moon-Kie. 2015. Beneath the Surface of White Supremacy. Stanford, CA: Stanford University Press.

-----. 2019. "The Enslaved, the Worker, and Du Bois's Black Reconstruction: Toward an

Underdiscipline of Antisociology." Sociology of Race and Ethnicity 5(2):157-168.

Hagerman, Margaret A. 2014. "White Families and Race: Colour-Blind and Color-Conscious

Approaches to White Racial Socialization.” Ethnic and Racial Studies 37(14):2598-2614.

-----. 2016. "Reproducing and Reworking Colorblind Racial Ideology: Acknowledging

Children's Agency in the White Habitus." Sociology of Race and Ethnicity 2(1):58-71.

Harris, Cheryl I. 1993. "Whiteness as Property." Harvard Law Review 106(8):1707-91.

Hughey, Matthew W., David G. Embrick and Ashley W. Doane. 2015. "Paving the Way for

Future Race Research: Exploring the Racial Mechanisms within a Color-Blind,

Racialized Social System." American Behavioral Scientist 59(1 1):1347-1357.

Itzigsohn, José and Karida L. Brown. 2020. The Sociology of W. E. B. Du Bois. New York: NYU Press.

Katznelson, Ira. 2005. When Affirmative Action was White. New York: W.W. Norton.

Lavelle, Kristen. 2017. "Under Siege in Any Era: White Threat and Victim Memories of the Civil Rights Era." Du Bois Review 14(2):515-534.

Maynard, Douglas W. 2006. "Cognition on the Ground." Discourse Studies 8(1):105-15.

McGoey, Linsey. 2012. "The Logic of Strategic Ignorance." The British Fournal of Sociology 63(3):553-576.

Meghji, Ali. 2019. "Activating Controlling Images in the Racialized Interaction Order: Black 
Middle-Class Interactions and the Creativity of Racist Action." Symbolic Interaction 42(2):229-249.

-----. 2021. "Just What Is Critical Race Theory, and What Is It Doing in British Sociology?

From 'BritCrit' to the Racialized Social System Approach." British Fournal of Sociology 72:347-359.

Mills, Charles W. 1997. The Racial Contract. Ithaca, NY: Cornell University Press.

------. 2007. "White Ignorance." Pp. 13-38 in Race and Epistemologies of Ignorance, edited by

S. Sullivan and N. Tuana. Albany: State University of New York Press.

Moore, Wendy Leo. 2020. "The Mechanisms of White Space(s)." American Behavioral Scientist 64(14)1946-1960.

Mueller, Jennifer C. 2013a. "The Social Reproduction of Systemic Racial Inequality." Ph.D.

Dissertation, Department of Sociology, Texas A\&M University, College Station, TX.

-----. 2013b. "Tracing Family, Teaching Race: Critical Race Pedagogy in the Millennial

Sociology Classroom." Teaching Sociology 41(2):172-187.

------. 2017. "Producing Colorblindness: Everyday Mechanisms of White Ignorance." Social Problems 64:219-238.

-----. 2020. "Racial Ideology or Racial Ignorance? An Alternative Theory of Racial Cognition." Sociological Theory 38(2):142-169.

Myers, Ella. 2019. "Beyond the Psychological Wage: Du Bois on White Dominion.” Political Theory 47(1):6-31.

Pan, J. C. 2020. "Why Diversity Training Isn't Enough." The New Republic. Retrieved June 2, 2021 (https://newrepublic.com/article/156032/diversity-training-isnt-enough-pamelanewkirk-robin-diangelo-books-reviews).

Perry, Pamela and Alexis Shotwell. 2009. "Relational Understanding and White Antiracist Praxis." Sociological Theory 27(1):33-50.

Rodriquez, Jason. 2006. "Color-Blind Ideology and the Cultural Appropriation of Hip-Hop." Journal of Contemporary Ethnography 35(6):645-668.

Salter, Phia S., Glenn Adams, and Michael J. Perez. 2018. "Racism in the Structure of Everyday Worlds: A Cultural-Psychological Perspective." Current Directions in Psychological Science 27(3):150-55.

Seamster, Louise and Victor Ray. 2018. "Against Teleology in the Study of Race: Towards the Abolition of the Progress Paradigm." Sociological Theory 36(4):315-42.

Shanks, Trina R. W. 2005. "The Homestead Act: A Major Asset-Building Policy in American History." Pp. 20-41 in Inclusion in the American Dream, edited by M.W. Sherraden. New York: Oxford University Press.

Shapiro, Thomas M. 2005. The Hidden Cost of Being African American. New York: Oxford University Press.

Somin, Ilya. 2015. "Rational Ignorance." Pp. 274-281 in Routledge International Handbook of Ignorance Studies, edited by M. Gross and L. McGoey. New York: Routledge.

Stark, Jordan G., Stacey Sinclair, and J. Nicole Shelton. 2021. "How University Diversity 
Rationales Inform Student Preferences and Outcomes." Proceedings of the National Academy of Sciences 118(16). DOI:10.1073/pnas.2013833118.

Strand, Michael and Omar Lizardo. 2015. "Beyond World Images: Belief as Embodied Action in the World." Sociological Theory 33(1):44-70.

Tavory, Iddo. 2018. "Between Situations: Anticipation, Rhythms, and the Theory of Interaction." Sociological Theory 36(2):117-133.

Tavory, Iddo and Nina Eliasoph. 2013. "Coordinating Futures: Toward a Theory of Anticipation." American Fournal of Sociology 118(4):908-942.

Thomas, James M. 2014. "Affect and the Sociology of Race: A Program for Critical Inquiry." Ethnicities 14(1):72-90.

Trepagnier, Barbara. 2010. Silent Racism. Boulder, CO: Paradigm Publishers.

Yamashita, Liann. 2020. "Uncle Kimo Doesn't Get It: Reinforcing Racial Apathy with Racist Humor." Sociological Inquiry 91(1):52-75.

Yan, Catalina Tang, Rabiatu Orlandimeje, Rachel Drucker and Adam J. Lang. 2021.

"Unsettling Reflexivity and Critical Race Pedagogy in Social Work Education." Social

Work Education. DOI:10.1080/02615479.2021.1924665. 